\title{
EMPATHY DEVELOPMENT WITH ACTIVE LEARNING FOR STUDENTS IN CLASS V ELEMENTARY SCHOOL
}

\author{
Nina Nurhasanah', Zulela Zulela², Etin Solihatin³ \\ 1,2,3Universitas Negeri Jakarta

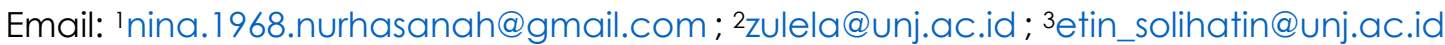

\begin{abstract}
The research aims to know the learning process with active learning in developing empathy for class $V$ students in elementary school. There are two research participants: SD Laboratory of PGSD FIP UNJ and SD Budi Wanita in Setiabudi Jakarta Indonesia. Research methods use a naturalistic qualitative method. The data collection process is doing by observation, interviews, and document analysis. The observation results analyzed by focused observation, taxonomy analysis, selected observation, component analysis, and theme analysis. The validity of the data is doing by extension of participation, the persistence of observation, and triangulation. The findings suggest that grade $V$ students in elementary school have been able to develop empathy. The strategies that teachers do in active learning to develop empathy in the form of role-playing, Jigsaw, discussion, group work, and use games performed on early activities, core activities, and end-of-learning activities. Using active learning in learning in class $\mathrm{V}$ in elementary school can develop students ' empathy.
\end{abstract}

Keywords: Active learning, empathy, Pancasila education and citizenship

\section{INTRODUCTION}

The globalization era marked by increasingly rapid technological progress in all fields of human life

There has been a change in the world of education. The orientation of the development of education is more focused on the vision of the future while still being rooted in the nation's culture. Therefore, the personal figure of Indonesian people is expecting to have not only academic intelligence but also moral intelligence and creativity and innovation to live productively in society. The educational process so far tends to separate students' thoughts and affections. That is what causes attitude learning to be less meaningful for students so that what learned does not seem to apply to students' daily lives. Therefore, it is necessary to develop students' effective competence in the learning process, especially to achieve moral intelligence, including empathy through the learning process at school.Empathy needs to develop in the school learning process. It can encourage students to treat others well.

Borba said that "empathy is the ability to identify with and feel another person's concerns" (empathy is the ability to understand the feelings and concerns of others) (Borba, 2001). This expert opinion is supported by Kohut in Taufik, who argues that empathy is a process in which a person thinks about the condition of others as if he was in the other person's position (Taufik, 2012). Research on empathy has demonstrated that people high on trait empathy are better able to understand the full effect of adverse outcomes on others because they can put themselves in those experiencing the negative outcome (Davis 1994; Barclay, 2014). 
According to Borba, there are three steps to build empathy, especially in children: The First teaching step helps the child develop an awareness of emotions and develop a feeling vocabulary. The Second Step provides ways to enhance the child's sensitivity to other people's feelings so that he becomes more aware of their needs and concerns. The last step helps expand the awareness of perspectives other than his own (Borba, 2001). For that step to be fulfilling, one way is to use active learning-based learning as an active learning sense is an activity that helps students to test their feelings, values, and Behaviors "(Silberman, 2006). Silberman described "active learning, and the students did many activities. They use thought (brain) to learn ideas, solve problems, and apply what they learn. Children also need models who show kindness or concern for others and encourage them to do. As Borba said, "empathy is the ability to identify with and feel another. At school, students who have empathy will feel that what other people feel is something they feel too. It can encourage students to treat others well. Students who have empathy will tend to understand their friends' feelings or emotions, making it easier for friends and helping them in the learning process. The students will quickly carry out discussions and group work that must understand each other and understand the feelings, emotions, or circumstances of friends.

\section{METHOD}

The research aims to obtain natural data about students' development process in elementary school $V$ class by using Pancasila education learning and active learning-based citizenship. Research conducted in laboratory Primary school PGSD FIP UNJ Setiabudi Jakarta Selatan Indonesia and Budi Wanita Private elementary School Jakarta Selatan Indonesia. The participants were female students 30 and men 16 and two of the $V$ class teachers in the 2nd semester of an even 2016/2017.

Similarly, in SD private Budi women, class $V$ teachers are already using learning Pancasila education and citizenship with active learning-based. Therefore, these two schools become the subject of research to see the process of learning Pancasila education and citizenship based active learning conducted by students and teachers.

The research uses a naturalistic qualitative method. Data collection process using observation and interview techniques. The research instruments used are observation sheets using field notes and interview transcripts. Primary data sources derived from field records and interview results, while secondary data sources are obtaining from documents in the form of a Learning Plan created and used by teachers in developing Pancasila education learning and active learningbased citizenship in the $V$ class. Other data sources derived from video recordings and photographs taken during the learning process of Pancasila education and citizenship based active learning in class $\mathrm{V}$ semester two years Doctrine of 2016/2017.

The data collection techniques used in this study are using observation, interviews, and document study. Observation with the type used is observation participating, descriptive observation, focused observation, and selected observation. It also studied documents related to research issues. The results of observations and interviews were made in the form of field notes (CL) and transcripts interviews. Data recording using field notes consisting of initial logging, expansion, and additional stages.

The observation is doing to students and teachers of class V SD laboratory PGSD FIP 
UNJ and private SD Budi Wanita as the data source. Observations were conducted in the classroom when teachers and students did the learning process with active learning. The interview conducted on the teacher of class $V$. The observation result is then written into the field record once it analyzed through domain analysis, taxonomy, theme analysis.

Based on field record data from the observation results as well as interviews gained findings that learning to use active learning can develop students 'empathy. Data on the observed results taken nine times during the learning process in the classroom and then analyzed by field notes show that learning using active learning can develop students ' empathy. This proven observation results look no student empathy changes for nine times the observation. Students who were not initially well-developed have gradually become more empathetic to fellow friends in the classroom.

\section{RESULTS}

The results showed that students' development of empathy obtained using the learning of Pancasila education and active learning-based citizenship in the $\mathrm{V}$ class elementary school. 1) Students' empathy develops using the learning process that uses discussions in the learning of Pancasila and Citizenship Education. 2) Students' empathy develops using a learning process that uses roleplaying activities in Educational Learning Pancasila and Citizenship. 3) The empathy of students develops by using games in learning education Pancasila and Kewarganegaan.

It is evident when students at the beginning of the learning process have not formed empathy optimally. After the learning process, Pancasila and citizenship education with active learning-based.

\section{DISCUSSION}

Teachers provide assignments to discuss in groups. After being discussed, each group performs a presentation. A student discussion can have many opportunities for social interaction with their peers in various activities. Students understand others precisely from attitudes, body language, facial expressions, and voice tones. Understand the expressions that others demonstrated and give the right reaction. Understand the sadness of others and give the right response. Shows that he understands the feelings of others.

Furthermore, learning activities using the role-playing method visible students perform processes of activities that able to develop students with fun learning and social interaction with peers that take place during the study activities. Role-playing activities where students given the task of playing a role in the school's organization during the study in which students show social sensitivity can see from the students' words, can understand the feelings of others with what the student said. Show the sensitivity of the needs and feelings of others. Students understand others precisely of body attitudes, body language, facial expressions, and voice tones with what students say. Also, students understand the expressions demonstrated by others and give the right reaction, as the students said. Students understand the sorrow of others and give the right response by seeing what the student said. Such practices and activities can perform in all kinds of contexts (face-to-face or online) and concerning any content (natural or social science, humanities) (Eva RimbauGilabert, 2018).

Active learning is learning that involves students in the process of thinking that can apply to all student learning processes. In line with that, according to Moh. Uzer Usman characteristics of active student 
learning are 1) intellectual-emotional involvement of students in the teaching and learning activities concerned, 2) assimilation and cognitive accommodation in the achievement of knowledge and 3) actions and direct experience of feedback (feedback) in the formation of skills, and appreciation and internalization of values in the formation of attitudes (Usman, 2004).

Furthermore, Silberman also said that for more effective active learning, the teacher could use various techniques, namely small group discussions and projects, presentations and debates, experiential exercises, field experiences, simulations, and case studies (Melvin L. Silberman, 1996). Bonwell's opinion in Chotimah is also in line with previous opinions that active learning has characteristics, including emphasizes the exploration of values and attitudes regarding the subject matter. Bonwell's opinion in Chotimah is also in line with previous opinions that active learning has characteristics, including emphasizes the exploration of values and attitudes regarding the subject matter (Chotimah, 2011). Besides the advantages of active learning in terms of its social dimension, students can learn various lessons about certain values between students, including tolerance and sharing (David A. Huffaker, 2003).

\section{CONCLUSION}

Pancasila education and citizenship that use the learning process by involving students in conducting various activities do feel and think. With such conditions, students able to develop an understanding of the many essential ideas to learn. Active-learning-based learning through active student involvement in learning can also develop high-level thinking skills, such as analysis, syntheses, and evaluation. It is related to the advantages of active learning, which is learning students with a pleasant atmosphere so that the material is hard to understand becomes not difficult for them. This active learning will make it easy for students to capture ongoing subject matter. The learning process becomes unboring and makes students more enjoying the lessons delivered, and does not make them difficult to understand the material. Active learning-based learning, students not only work on assignments, but can also use the brain, examine ideas, solve problems, and implement them in societal life. Learning becomes more exciting and fun, eager, and not dull students. Learning becomes more enjoyable, as many learning activities are varied and challenging and involve students as a whole, both physical and mental, in learning. Also, the advantage of active learning from its social dimension is that students can learn various lessons about certain values between students and others, including tolerance and sharing (David A. Huffaker, 2003).

\section{ACKNOWLEDGMENTS}

We would like to thank the parties who helped this research. Thanks to the Jakarta State of University. Thanks to the Head of Elementary School at SD Laboratorium PGSD FIP UNJ, SDS Budi Wanita, who given permission to research to conduct research and retrieve data.Thanks to the students and teachers at the research 
schools who have helped in taking research data.

Researchers give thanks to all who helped. Thanks to research teams who have worked together during the research process and data collection and reporting of research results.

\section{REFERENCES}

Barclay, D. B. W. - L. J. (2014). The Face of Fairness: Self-Awareness as a Means to Promote Fairness among Managers with Low Empathy. J Bus Ethics. https://doi.org/DOI 10.1007/s10551-014-2357-7

Borba, M. (2001). Building Moral Intelligence The Seven Essential Virtues That Teach Kids to Do the Right Thing. Growth (Lakeland). San Fransisco: Jossey-Bass.

David A. Huffaker, S. L. C. (2003). The New Science of Learning: Active Learning, Metacognition, and Transfer of Knowledge in E-Learning Applications. J. EDUCATIONAL COMPUTING RESEARCH, VOl. 29((3)), 325-334. Retrieved from Baywood Publishing Co., Inc

Eva Rimbau-Gilabert. (2018). Active Learning Strategies in Higher Education. In M. D. L. Anastasia Misseyanni, Paraskevi Papadopoulou, Christina Marouli (Ed.), Innovation, and Creativity, (p. 244). Catalunya: emerald insight. https://doi.org/k to this dohhttps://doi.org/10.1108/978-178714-487-320181008

Giyati Retnowati, Rose Mini Agoes Salim, A. Y. S. (2018). Effectiveness of Picture Story Books Reading to Increase Kindness in Children Aged 5-6 Years. Lingua Cultura, 12(1), 89-95. https://doi.org/DOI:

10.21512/lc.v12i1.2095

Nabors, Karen Linda Dunn, C. C. B. A. D. H.
A. K. R. A. S. (2012). Active Learning Strategies in Classroom Teaching: Practices of Associate Degree Nurse Educators in A Southern State. University of Alabama. https://doi.org/file://C:/Users/ASUS/D ocuments/ArtikBarclay, D. B. W. - L. J. (2014). The Face of Fairness: SelfAwareness as a Means to Promote Fairness among Managers with Low Empathy. J Bus Ethics. https://doi.org/DOI 10.1007/s10551014-2357-7

Borba, M. (2001). Building Moral Intelligence The Seven Essential Virtues That Teach Kids to Do the Right Thing. Growth (Lakeland). San Fransisco: Jossey-Bass.

David A. Huffaker, S. L. C. (2003). The New Science of Learning: Active Learning, Metacognition, and Transfer of Knowledge in E-Learning Applications. J. EDUCATIONAL COMPUTING RESEARCH, VOI. 29((3)), 325-334. Retrieved from Baywood Publishing Co., Inc

Eva Rimbau-Gilabert. (2018). Active Learning Strategies in Higher Education. In M. D. L. Anastasia Misseyanni, Paraskevi Papadopoulou, Christina Marouli (Ed.), Innovation, and Creativity, (p. 244). Catalunya: emerald insight. https://doi.org/k to this dohhttps://doi.org/10.1108/978-178714-487-320181008

Giyati Retnowati, Rose Mini Agoes Salim, A. Y. S. (2018). Effectiveness of Picture Story Books Reading to Increase Kindness in Children Aged 5-6 Years. Lingua Cultura, 12(1), 89-95. https://doi.org/DOl: 10.21512/lc.v12i1.2095

Nabors, Karen Linda Dunn, C. C. B. A. D. H. A. K. R. A. S. (2012). Active Learning Strategies in Classroom Teaching: Practices of Associate Degree Nurse 
Educators in A Southern State. University of Alabama.

https://doi.org/file:///C:/Users/ASUS/D ocuments/Artikel\%20Active\%20Learni ng-oke/active\%20learningdisertasi.pdf

Silberman, M. L. (1996). Active Learning 101 Strategies to Teach Any Subject. Massachusetts: Allyn \&Bacon. 